\title{
THE ROLE OF PERSONALITY TRAITS IN STATUS CONSUMPTION, A STUDY INTO DOMESTIC AND FOREIGN BRANDS
}

\author{
*Aysel ERCiş \\ *Sevtap ÜNAL \\ ***Bilsen BİLGíLi \\ *Atatürk University, Turkey \\ ***Kocaeli University, Turkey
}

\begin{abstract}
In this study, it was aimed to determine whether personal influence and self-monitoring had an impact on status consumption tendencies of consumers or not. The relationship between status consumption in consumer behaviors and domestic/foreign brand preferences was also investigated. For this purpose, 382 questionnaires were administered to the consumers shopping in Ýstinye Park and Kanyon shopping malls in Istanbul (Turkey). To test the research model, Structural Equation Model (SEM) test was used by using LISREL 8.7 statistics programme. In order to determine the relationship between brand preferences and status consumption tendencies of the respondents, correlation analysis was conducted by using SPSS 17.0 program. According to the results of the research, it was determined that personal influence and self-monitoring had an impact on status consumption. It was also found out that prestige and foreign brands were preferred more in status consumption. According to the results obtained, some suggestions were made for the companies in ready-to-wear sectors.
\end{abstract}

Keywords: Consumer Behavior; Status Consumption; Self- monitoring;Personal Influence

\section{INTRODUCTION}

Conspicuous consumption is quite an old phenomenon. It is defined as the spending mainly for the purpose of displaying the person's status and prestige to the surrounding others. Under these consumptions lies the perception of the purchased products as an indicator of prestige by the surrounding others. The person is satisfied with the buying decision when the surrounding others see the purchased product as a product of prestige (Kilsheimer, 1993). In several studies conducted in the field of marketing, conspicuous and status consumption has been considered as the concepts that define the same phenomenon. Kilsheimer defined status consumption as "conspicuous consumption that a person does to display his/her status or prestige to the surrounding others" (Kilsheimer, 1993: 341). Researchers stated that these two concepts were related but distinct phenomena (Eastman, Goldsmithand Flynn, 1999; Roberts, Gwin and Martinez, 2004). Conspicuous consumption is the purchase of goods and services consumed in the society for the purpose of enhancing one's prestige in the society and the use of these goods and services to influence other people in the society and satisfy one's ego (O'Cass and McEwen, 2005). Status consumption is defined as "the motivational process by which individuals show their social standing through the purchase of products that symbolize status for the surrounding others" (Heaney, Goldsmith, Jusoh, 2005:85). As it is seen, there are differences between the two terms. While ostentation is important in conspicuous consumption, there is a tendency to consume according to the social class in status consumption. The common point for both terms is that such spending is done to give special messages to the surrounding others. For this reason, personal traits play an important role in such spending because the conspicuous and status consumption tendencies are also high among those who are more inclined to get influenced by the social surrounding and behave accordingly (O'Cass and McEwen, 2005).

For this reason, in the study it was aimed to investigate only status consumption and determine which types of foreign and domestic ready-to-wear brands are preferred in status consumption. Additionally, in case of consumer's assessing the brands as indicators of status and prestige, the role of their ego and level of influence by the social surrounding were investigated. In the first part, theoretical information was provided about conspicuous-status consumption, self-monitoring and personal influence; 
in the second part, the conspicuous and status consumer tendencies and their foreign or domestic brand preferences were examined.

\section{The Concept and Characteristics of Conspicuous and Status Consumption}

Conspicuous and status consumption was first mentioned in the studies conducted by Veblen on social classes. Veblen stated that conspicuous consumption is the spending done by the upper class and the other social classes who want to resemble them for the purpose of ostentation (Mason, 2001).

The researches related to status and conspicuous consumption mostly carried out by sociologists and anthropologists were conducted to understand the consumer behavior in the field of marketing. In status consumption, the ownership of some products and brands or the mood created by using them can be perceived as a status symbol since purchase of some products and brands is accepted as one of the most important indicators of success and power. Not all such spending is thought to be for the purpose of ostentation. Thus, status consumption is defined as "the motivational process by which individuals show their social standing through the purchase of products that symbolize status for the surrounding others" (Heaney, Goldsmith and Jusoh, 2005:85). Conspicuous consumption is defined as "the purchase of goods and services consumed in the society for the purpose of enhancing one's prestige in the society and the use of these goods and services to influence other people in the society and satisfy one's ego" (O'Cass and McEwen, 2005: 27).

O'Cass and McEwen, in their study (2005), argued that status and conspicuous consumption were different phenomena and tested it. According to the results they found out, status and conspicuous consumption are separate but related constructs. Taking this into consideration, conspicuous consumption and status consumption were examined separately in this study.

In the researches conducted about conspicuous and status consumption, demographic, personal and cultural characteristics of the individuals who are interested in conspicuous and status consumption were examined (Kilsheimer 1993; Marcoux, Filiatrault and Cheron 1997; Eastman, Goldsmith and Flynn 1999; Goldsmith, Clark and Goldsmith 2006). According to the research results, personal characteristics such as materialism (Eastman et al. 1997; Roberts 2000; Rose and DeJesus, 2007), social ego (Wong (1997), being different (Heaney, Goldsmith and Jusoh, 2005) and culture (Chen 2002) played an important role in such kind of spending. Conspicuous consumption tendency is higher for those who are materialist, care about social ego and have high personal influence (Bearden, Netemeyer and Teel, 1989).

Kilsheimer (1993), in his dissertation, developed a scale to measure status consumption. The researcher considered status and conspicuous consumption as the same phenomena. The author examined status consumption in detail and the antecedents, dimensions and results of the behavior. The antecedents of status consumption includes consumption for status, supporting ego by using the product, moving up the social ladder, culture, product involving status symbol and ignoring functional characteristics of the product. The three dimensions of status consumption are; socializing, showing interest in consumption to gain status, and purchasing other than functional reasons. The results are; purchasing status products, choosing status brands, positive attributions to status brands, using different media and communication sources for status products, benefiting from different type of spending to purchase these products, and low price sensitivity.

Marcoux, Filiatrault and Cheron (1997) examined conspicuous consumption behaviors of Polish students. According to the results they found out, conspicuous consumption is quite common among the students and the determinants of such consumption are generally brands of American origin. In their study, the researchers also developed conspicuous consumption scale including five dimensions. The dimensions of conspicuous consumption are as follows: 1. Materialistic hedonism, 2. Communication of belonging to/dissociation from a group, 3. social status demonstration, 4. interpersonal mediation, 5. Ostentation.

In conspicuous consumption, people who admire others try to be like them. A general characteristic of conspicuous consumption is that other people perceive products as symbols of wealth instead of bene-fiting from them. The reason for this is the desire to exaggeratedly show the product to the surround- 
ing others (Mason, 2001, Wong, 1997). In a sense, people attempt to show their purchasing power to others. With these efforts, they give messages to others to show that they are wealthy, different, and belong to a specific group (Amaldoss and Jain, 2005). Therefore, only luxury and expensive goods are preferred in conspicuous consumption. It is particularly important that the goods to be consumed in the society be luxury and expensive (Eastman, Goldsmith and Flynn, 1999). The level of satisfaction is determined depending on the reactions of other people to the product. Rather than economical and psychological advantages to be gained from the product, consumption is shaped by the influence of social environment. Admiration of the product/brand by the surrounding others increases the satisfaction level of the individual (Chen, 2002, Chen, et. al 2005, Mason, 2001).

Wong (1997) examined the relationship between conspicuous consumption, materialism and self. According to the results of the study, those who are materialistic and care about social self are more inclined to conspicuous consumption. Eastman et al. (1997) investigated the relationship between status consumption and materialism in a cross-cultural study. In the study conducted on American, Chinese and Mexican students, they found out that there are different points of view on materialism and status consumption, but there is a relationship between status consumption and materialism in the three cultures. Goldsmith et al. (2006) investigated the demographic characteristics of market mavens and the relationship of market mavenism with status consumption and innovativeness. In identifying market mavens, it was determined that demographic characteristics are not determinants. In determining market mavens, innovativeness and status consumption were found out to be more explanatory. Heaney, Goldsmith and Jusoh (2005), in their study, examined the relationship between materialism, being different and status consumption. The researcher stated that materialism and status consumption are separate but related concepts. According to the study, there is a relationship between materialism, uniqueness and status consumption. Roberts (2000) investigated the relationship between compulsive buying, materialism and status consumption. According to the results of the study, those who are materialists and have a high tendency in status consumption are more inclined to compulsive buying. Roberts, Gwin and Martinez (2004), in their study, examined the effect of family wealth, structure, and consumption tendency on compulsive buying and materialism. Additionally, they examined the relationship between compulsive buying and status consumption which is considered as intervening variable. According to the results, there is a relationship between compulsive buying and family's being materialist or not, family's being together or not (death, separation) and family's having a tendency in status consumption. The tendency towards status consumption and compulsive buying in materialistic and disrupted families is higher.

Furthermore, Marcoux, Filiatrault and Cheron (1997) examined conspicuous consumption behaviors of the students. They tried to determine the conspicuous consumption tendencies of the students in the direction of their preferences of Polish and American brands. According to the results of the study, conspicuous consumption is quite common and brands of American origin are generally more preferred in such kind of consumption. Considering the assumption that foreign brands are perceived by the consumers as an indicator of more prestige, it is hypothesized that

\section{H1: Consumers prefer foreign brands in status consumption.}

\section{Self and Self-Monitoring}

It is not possible to think of self-concept, personality, life style, and values separately while examining consumer behaviors. With the joint effect of these variables, also expressed as psychographic variables, consumer is directed to a specific behavior. Especially, self-concept appears to have a "fixed" or "adaptable" structure according to both social surrounding and personal traits. Therefore, in understanding consumer behaviors, self-concept provides descriptive information about the inner and external world of consumers (Aaker, 1999).

Self, in general, is one's perception of one's own being or identity. It is the evaluation and interpretation of individual's own characteristics by comparing their external surrounding and other people (Reed II., 2002: 236; Loroz, 2004: 326). Individuals are aware of their own self and usually define their self-concepts according to their relations with the others (Wee and Ming, 2003: 209). It is stated that self-concept has three basic dimensions. These are; the material self (one's body, physical elements and material assets), the social self (one's desire to be like the other people) and the spiritual self (one's inner world) (Abe, Bagozzi and Sadarangani, 1996: 98). Therefore, it is not possible to talk 
about only one self-concept for individuals. A general distinction is made as follows: Real self is the self that an individual has in the direction of his/her characteristics. Ideal self is the composite of the characteristics that an individual desires to have (Koç, 2007: 176; Solomon, 2007: 157). Real social self means how the others perceive the individual and ideal social self means how the individual wants the others to perceive him/her (Hong and Zinkhan, 1995: 54; Sandra, 2002: 53).

Another concept associated with the self is self-monitoring. Self-monitoring was first used by Synder in 1974. Self-monitoring is the degree to which individuals observe the situations and behaviors in their surroundings and controls their behaviors accordingly (Aaker, 1999: 47; Darley and Lim, 1992: 332; Polat and Umay, 2003: 198). That is, it is the ability to control the susceptibility and reactions of others. Two types of self-monitoring are mentioned. First, high self-monitoring; second, low selfmonitoring. High self-monitoring means adapting behaviors according to the social patterns. These people monitors social cues very carefully and do not exhibit any behaviors other than those. Low self -monitors do not get influenced by the external surrounding while exhibiting their behaviors. These people do not have the ability to modify themselves according to the social cues and behavioral patterns. They even do not want to do such a thing. On the contrary, they do what they know in any setting and under any circumstances. Therefore, it is seen that these people do not pay more attention to social norms and social self. On the other hand, it is found out that high self-monitors pay great attention to ideal social self (Graef, 1996; O'Cass and McEwen, 2005; Ricks and Veneziano, 1998; Spangenberg and Sprott, 2006).

O'Cass, in his study (2000), developed self-monitoring scale and divided it into two subgroups as selfmonitoring susceptibility and self-monitoring tendency. The researcher argued that self-monitoring did not constitute one dimension and that two-factor model would be more useful to explain consumer behaviors. Self-monitoring susceptibility measures individuals' perception level of environment, whereas self-monitoring tendency measures the conformity of behaviors to the environment.

Individuals' having high and low self-monitoring characteristics enables them to interpret their surrounding and the world and show what kind of personality they exhibit. It is argued that five basic characteristics of self-monitoring play an important role in this: 1.the importance individual gives to social approval in expressing themselves, 2.the level of individual's paying attention to social comparison, 3.individual's ability to adapt their behaviors to the surrounding and control them, 4. the characteristics of using this ability in specific situations, and 5.indvidual's being consistent or changeable in expressing themselves and their behaviors (Bearden, Shuptrine and Teel, 1989: 703). For example, the things high self-monitors should do or not are determined by their surroundings because these individuals pay attention to external cues and stimulants (Lammers, 2002). They are also evaluated as good actors that can get adapted to any circumstances. They are quite social people. They have a lot of friends. However, they are not sincere with their friends. Friends are those chosen to help them adapt to different settings. Each friend is influential on their own surrounding. Although high self-monitors have different behavior patterns according to the situations and conditions, they have motivating aims. This aim is to be a beloved, wanted and admired person (Ricks and Veneziano, 1998; Rose and DeJesus, 2007). Low self-monitors pays more attention to the cues and stimulants from their inner world. Therefore, they choose friends that have highly similar attitudes (Lammers, 2002). The reason for such a selection is that they increase their strength to express themselves and the level of their approval by means of individuals like them (Harnish and Bridges, 2006).

According to the researches, high self-monitors pay attention to the approval of the attraction and quality of the message source by the others while making decisions. Low self-monitors pays attention that message source should be an expert while making decisions. High self-monitors get influenced by the advertisements emphasizing image of the product. On the contrary, for low self-monitors advertisements emphasizing functional characteristics of the product are more influential because these individuals make decisions according to their functional characteristics (Graeff, 1996). Shavitt, Lowrey and Han (1992) examined how self-monitoring affected the attitudes towards advertisements. According to the results, high self-monitors mostly assessed the advertisements in the direction of social surrounding. Low self-monitors paid attention to the utilitarian message cues of the advertisements. Harnish and Bridges (2006) investigated the relationship between the characteristics of selfmonitoring and making social comparisons with others, and individuals they prefer to get information. According to the results, high self-monitors make more social comparisons. While comparing they choose the information sources they use among high-self monitors like them. Low self-monitors do not have such a tendency. 
Graeff (1996), in his study, examined the relationship between the preferences on consumed brands personally and among other people and self. Consumers are greatly influenced by the point of view of the surrounding others in the brand preference of consumed products in a way the other people can see. The same situation is not valid for the brands of the personally consumed products. For high selfmonitors, the brands to be consumed among other people mostly depend on their reaction to the brand. Low self-monitors, on the other hand, get affected less by the reactions of the other people in their preference of brands. Rose and DeJesus (2007), in their study, examined the relationship between materialism and self-monitoring. It was seen that high self-monitors were more inclined to materialism. The researcher stated that having expensive and more products means approval by society for high self-monitors. Hog, Cox and Keeling (2000), in their study, examined the relationship between selfimage of the individual and product/brand image. They investigated brand image evaluations of consumers in congruence with their self for the brands of alcoholic soft drinks. The results show that self -monitoring of the consumers in their preferences of alcoholic soft drink brands plays a distinctive role. The preferences of high self-monitors can change depending on the place and setting where they will consume drinks. For those individuals it is quite important for the drink to support individual's self-image. For low self-monitors, image of the drink is not important, its content is important. A similar study was conducted by Ratner and Kahn (2002). They examined the influence level of the consumers by their surroundings and self-monitoring in variety-seeking. According to the results, consumers seek for more kinds and prefer different brands since they are alone in the setting they interact with people. Self monitoring is effective on variety seeking as an intervening variable. For high selfmonitors, the tendency to image-oriented variety-seeking is higher.

Thus, the following were hypothesized:

H2: Self-monitoring has an impact on status consumption.

\section{Relationship of Personal Influence with Self and Status Consumption}

Consumers mostly make decisions under the impact of their surroundings. Especially the advisory groups that an individual asks for advice are quite influential on consumer behaviors. The individual sees the reference group as an important data source (Solomon, 2007; Mowen, 1993).

The effect of the reference group on consumer behavior gets affected by two factors. These are; the goods/brand is luxury or compulsory goods, and the use of product/brand personally or in common areas. When the product has the status of a luxury goods and is used in common areas, the reference group has a strong effect on both product and brand choices. In case of a product for personal use or a compulsory product, the effect of reference group is weak (Solomon, 2007: 382). People interested in conspicuous and status consumption want to give some messages by showing other people either their social status or the things they own. Additionally, satisfaction with these consumptions depends on other people's or reference group's approval of these goods. Therefore, they direct people towards such kind of consumption (Amaldoss and Jain, 2005; Chen, 2002; Kilsheimer, 1993).

It is possible to find several researches investigating the impact of reference groups on consumer behavior. (Ford and Ellis, 1980; Graef, 1996; Harnish and Bridges, 2006; Ratner, Kahn, 2002). Bearden, Netemeyer and Teel (1989), in their study, developed a scale to determine the influence levels of consumers from other people. They argued that individuals' interaction with their surroundings constitutes two basic dimensions as normative and informational. That is, people interact by gathering information from reference groups or imitating their preferences. Escalas and Bettman (2005), in their study, examined the effect of the self and reference groups on brand meaning of consumers. Individuals prefer brands that support their self. However, brand meaning to support the self changes depending on the reference group's point of view. Thus, the following were hypothesized:

\section{H3: Personal Influence has an impact on status consumption}

The model developed for the purpose and hypotheses of the research is shown in Figure 1. 
Figure 1: Research Design

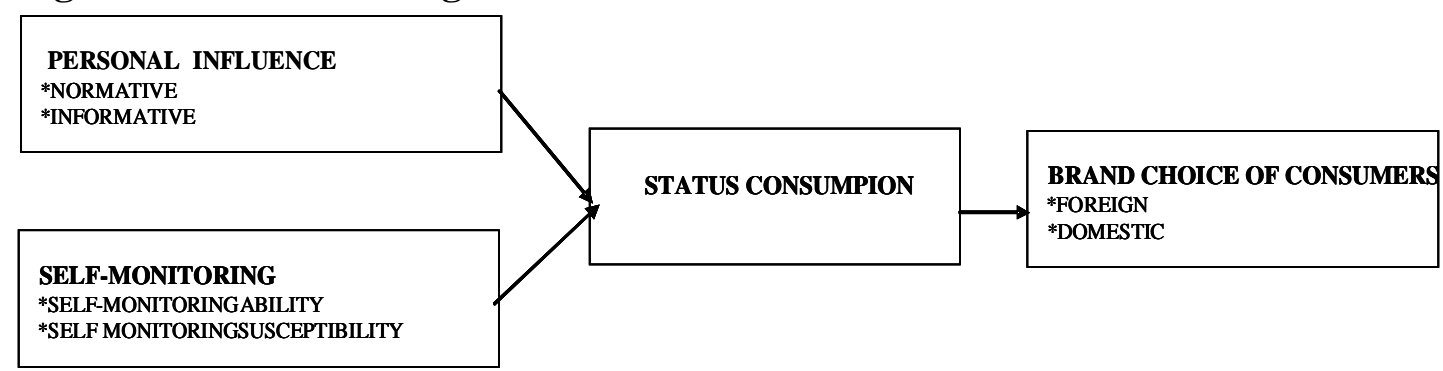

\section{RESEARCH DESIGN}

\section{Method}

Within the scope of the study, consumers shopping in two shopping malls selling foreign and domestic luxury-wear brands in Ýstanbul (Kanyon and Ýstinye Park Shopping Malls) were included. Sample size of the study was determined as 400, representing 95\% confidence intervals with an error margin of 5\%. Firstly, data were gathered by survey method. As a survey method, convenience sampling, one of the non-probabilistic sample methods, was used. Prepared surveys were administered to the respondents during weekdays (Monday, Wednesday and Friday) and weekends at 12.00-22.00 pm. for 3 weeks in the shopping centers mentioned above during March 2010.

There were five groups of close-ended questions in the survey to be measured on nominal, ordinal, and interval scales. The first group of questions was prepared to determine the demographic characteristics of the respondents. The second group was arranged to determine brands which are considered as luxury in ready-to-wear brands and the purchase of brands by the respondents during the last two years. There were 20 luxury and non-luxury ready-to-wear brands (10 domestic - 10 foreign) in the survey. Respondents were asked to mark the brands they considered as luxury brands and determine which brands they bought during the last two years. In addition, they were asked to mark which brands were domestic and foreign. Thus, respondents' luxury brand knowledge, choices and foreign brand rate in these choices were determined. The third group of questions was prepared to determine status consumption tendencies, the fourth group was prepared to determine self- monitoring, and the fifth group of questions was prepared to determine the level of personal influence.

Status consumption tendency was tested by the scale developed by Eastman, Goldsmith and Flynn (1999), self-monitoring by the scale developed by O'Cass' (2000) and the level of personal influence by the scale developed by Bearden, Netemeyer and Teel (1989). Items were measured on a 5point Likert by using SPSS 17.0 and Lisrel 8.3 statistical programmes. In data analysis, frequency distributions, confirmatory factor analysis, Correlasyon analysis and Structural Equation Model (SEM) test were used.

\section{Data analysis and hypotheses test results}

Frequency distributions of the demographic characteristics of the respondents participated in the research was shown in Table 1.

$56 \%$ of the respondents were female, $65.5 \%$ were between the ages 28 and $47,67.8 \%$ were university graduates and postgraduates, and 56.5\% were single. The level of income of $64.2 \%$ of the respondents were $6001 \mathrm{TL}$ and over. $36.9 \%$ were working for private sector. The other professional groups showed a close distribution with each other.

\section{Ready-to-wear brand preferences and buying behaviors of respondents}

In order to determine the status consumption preferences and behaviors of the respondents, 20 readyto-wear brands, prestige and non-prestige, were given to the respondents in a list and they were asked to mark the prestige brands. Then they were asked to mark the brands they bought during the last 2 years. Thus, the level of prestige brand preferences of the respondents was tried to be determined. The results were shown in Table 2. 
Journal of Global Strategic Management | V. 4 | N. 2 | 2010-December | isma.info | 17-33 | DOI: 10.20460/JGSM.2010415822

\begin{tabular}{|c|c|c|c|}
\hline \multicolumn{4}{|c|}{ Table 1: Demographic Characteristics of Respondents } \\
\hline Demographic & & Number & Percent \\
\hline \multirow[t]{2}{*}{ Gender } & Female & 214 & 56.0 \\
\hline & Male & 168 & 44.0 \\
\hline \multirow[t]{5}{*}{ Age } & $18-27$ & 95 & 24.9 \\
\hline & $28-37$ & 184 & 47.4 \\
\hline & $38-47$ & 69 & 18.1 \\
\hline & $47-58$ & 27 & 7.1 \\
\hline & 58 and over & 10 & 2.6 \\
\hline \multirow[t]{4}{*}{ Education } & Primary Education & 14 & 3.7 \\
\hline & Secondary Education & 109 & 28.5 \\
\hline & University & 244 & 63.9 \\
\hline & Postgraduate & 15 & 3.9 \\
\hline \multirow[t]{2}{*}{ Marital Status } & Married & 166 & 43.5 \\
\hline & Single & 216 & 56.5 \\
\hline \multirow[t]{5}{*}{ Monthly Average Income Level of the Family } & $0-2000 \mathrm{TL}$ & 18 & 4.7 \\
\hline & $2001-4000 \mathrm{TL}$ & 65 & 17 \\
\hline & $4001-6000 \mathrm{TL}$ & 54 & 14.1 \\
\hline & $6001-8000 \mathrm{TL}$ & 121 & 31.7 \\
\hline & 8001 and over & 124 & 32.5 \\
\hline \multirow[t]{8}{*}{ Profession } & Civil Servant & 46 & 12.0 \\
\hline & Worker & 9 & 2.4 \\
\hline & Self-employed & 43 & 11.3 \\
\hline & Those Working for Private Sector & 141 & 36.9 \\
\hline & Housewife & 42 & 11.0 \\
\hline & Industrialist/Businessman & 53 & 13.9 \\
\hline & Student & 42 & 11.0 \\
\hline & Retired & 6 & 1.6 \\
\hline \multicolumn{2}{|l|}{ TOTAL } & 382 & 100.0 \\
\hline
\end{tabular}

As seen in Table 2, the level of brand recognition of the respondents was high. The level of prestige brand buying of the respondents was $30 \%$ on average. However, as seen in Table 2, respondents' distinctions of foreign and domestic brands were not fully correct. It was observed that respondents marked some domestic brands (Network, Machka, Oxxo, Colin's) as foreign brands.

\section{Testing of research model}

In the study, confirmatory factor analysis was used to test personal influence, self-monitoring and status consumption scales (the tables indicating the mean and standard deviation values of the scales were presented in the annex to this paper). The variables indicating negative variance, exceeding standard coefficients (very close to 1.0) or presenting high standard error values were checked (Hair et al., 1998, p. 610) and inappropriate variables were eliminated.

Firstly, personal influence scale was tested. It was seen that model fit values of the scale was not on an acceptable level. In the direction of the suggested modifications, with the elimination of 4 variables, 2 from the "normative" dimension and 2 from the "informative" dimension, the scale was on an acceptable level. According to the scale developed by Bearden, Netemeyer and Teel (1989), interpersonal influence constitutes two dimensions as normative and informative. As a result of the confirmatory factor analysis, it was seen that the scale developed by the authors was consistent with our sample. The model fit values before and after modifications were shown in Table 3. 
Table 2 : Knowledge and Preference Levels of Respondents on Ready-To-Wear Brands

\begin{tabular}{|c|c|c|c|c|c|c|}
\hline \multirow[b]{2}{*}{ Brand Name } & \multicolumn{2}{|c|}{$\begin{array}{l}\text { Prestige Brand Level of } \\
\text { Recognition }\end{array}$} & \multicolumn{2}{|c|}{$\begin{array}{l}\text { Prestige Brand } \\
\text { Level of Purchase }\end{array}$} & \multicolumn{2}{|c|}{$\begin{array}{l}\text { Foreign Brand Level of } \\
\text { Recognition }\end{array}$} \\
\hline & No & Percent & No & Percent & No & Percent \\
\hline Network & 292 & 76.4 & 130 & 34.0 & 325 & 85.1 \\
\hline MaxMara & 284 & 74.3 & 17 & 04.4 & 317 & 83.1 \\
\hline Beymen & 330 & 86.3 & 122 & 32.0 & 94 & 24.6 \\
\hline Armani & 349 & 91.3 & 90 & 23.4 & 219 & 57.3 \\
\hline Vakko & 330 & 86.3 & 111 & 29.1 & 100 & 26.1 \\
\hline Oxxo & 276 & 72.3 & 112 & 29.3 & 301 & 78.9 \\
\hline Koton & 283 & 74.1 & 48 & 12.5 & 212 & 55.5 \\
\hline İpekyol & 250 & 65.4 & 150 & 32.3 & 40 & 10.5 \\
\hline Moschino & 289 & 75.7 & 26 & 06.8 & 296 & 77.4 \\
\hline Adil Işık & 260 & 68.1 & 45 & 12 & 44 & 11.5 \\
\hline Zara & 269 & 70.4 & 79 & 23 & 25 & 06.5 \\
\hline Machka & 278 & 72.8 & 49 & 29 & 315 & 82.5 \\
\hline Burberry & 328 & 85.9 & 134 & 35.1 & 350 & 91.6 \\
\hline Polo Garage & 327 & 85.6 & 160 & 41.9 & 331 & 86.6 \\
\hline Quicksilver & 289 & 75.7 & 47 & 12.3 & 340 & 89.0 \\
\hline LC Waikiki & 248 & 65.0 & 90 & 23.6 & 236 & 61.8 \\
\hline Gucci & 328 & 85.9 & 132 & 34.6 & 342 & 89.5 \\
\hline Colin's & 275 & 72.1 & 91 & 23.8 & 285 & 74.6 \\
\hline Marks\&Spencer & 298 & 78.0 & 82 & 23 & 341 & 89.3 \\
\hline Louis Vuitton & 336 & 88.0 & 52 & 13.6 & 346 & 90.5 \\
\hline
\end{tabular}

\begin{tabular}{|c|c|c|c|}
\hline \multicolumn{4}{|c|}{ Table 3: Personal Influence Scale Test } \\
\hline Fit Index & Before Modification & After Modification & Acceptable Fit \\
\hline \multicolumn{4}{|c|}{ Absolute Fit Value } \\
\hline Chi-square $\left(\mathrm{X}^{2}\right)$ & 529.93 & 75.86 & \\
\hline Degree of freedom & 52 & 18 & \\
\hline Chi-square/degree of freedom & 10.17 & 4.21 & $1-5$ \\
\hline GFI & 0.78 & 0.92 & $0,90 \leq \mathrm{GFI} \leq 0,95$ \\
\hline AGFI & 0.67 & 0.85 & $0,85 \leq \mathrm{AGFI} \leq 0,90$ \\
\hline RMSR & 0.11 & 0.070 & $0,05 \leq$ RMSR $\leq 0,08$ \\
\hline RMSEA & 0.17 & 0.080 & $0,05 \leq$ RMSEA $\leq 0,08$ \\
\hline \multicolumn{4}{|c|}{ Incremental Fit Value } \\
\hline CFI & 0.93 & 0.96 & $0,95 \leq \mathrm{CFI} \leq 0,97$ \\
\hline NNFI & 0.91 & 0.93 & $0,95 \leq \mathrm{NNFI} \leq 0,97$ \\
\hline NFI & 0.92 & 0.95 & $0,95 \leq \mathrm{NFI} \leq 0,97$ \\
\hline
\end{tabular}

Secondly, confirmatory factor analysis was conducted for self-monitoring scale consisting of two dimensions as self-monitoring ability and self-monitoring susceptibility. It was found out that model fit values were not on an acceptable level. In the direction of the suggested modifications, 4 variables, 3 from self-monitoring ability dimension and 1 from self-monitoring susceptibility dimension, were eliminated. After modification it was observed that model fit values were on an acceptable level. The results were shown in Table 4. 
Journal of Global Strategic Management | V. 4 | N. 2 | 2010-December | isma.info | 17-33 | DOI: 10.20460/JGSM.2010415822

\begin{tabular}{|c|c|c|c|}
\hline \multicolumn{4}{|c|}{ Table 4: Self-Monitoring Scale Test } \\
\hline Fit Index & Before Modification & After Modification & Acceptable Fit \\
\hline \multicolumn{4}{|c|}{ Absolute Fit Value } \\
\hline Chi-square $\left(\mathrm{X}^{2}\right)$ & 283.97 & 54.17 & \\
\hline Degree of freedom & 52 & 18 & \\
\hline Chi-square/degree of freedom & 5,46 & 3.01 & $1-5$ \\
\hline GFI & 0.87 & 0.97 & $0,90 \leq \mathrm{GFI} \leq 0,95$ \\
\hline AGFI & 0.80 & 0.93 & $0,85 \leq \mathrm{AGFI} \leq 0,90$ \\
\hline RMSR & 0.11 & 0.054 & $0,05 \leq \mathrm{RMSR} \leq 0,08$ \\
\hline RMSEA & 0.12 & 0.073 & $0,05 \leq$ RMSEA $\leq 0,08$ \\
\hline \multicolumn{3}{|c|}{ Incremental Fit Value } & \\
\hline CFI & 0.86 & 0.95 & $0,95 \leq \mathrm{CFI} \leq 0,97$ \\
\hline NNFI & 0.83 & 0.93 & $0,95 \leq \mathrm{NNFI} \leq 0,97$ \\
\hline NFI & 0.84 & 0.93 & $0,95 \leq \mathrm{NFI} \leq 0,97$ \\
\hline
\end{tabular}

Confirmatory factor analysis was conducted for status consumption scale, one of the variables of the research model, and it was determined that model fit values were not on an acceptable level.

In the directions of the suggested modifications, 1 variable was eliminated from status consumption scale. Model fit values were on an acceptable level after modification. The results were shown in Table 5 .

\begin{tabular}{|c|c|c|c|}
\hline \multicolumn{4}{|c|}{ Table 5: Status Consumption Scale Test } \\
\hline Fit Index & Before Modification & After Modification & Acceptable Fit \\
\hline \multicolumn{4}{|l|}{ Absolute Fit Value } \\
\hline Chi-square $\left(\mathrm{X}^{2}\right)$ & 23.53 & 3.72 & \\
\hline Degree of freedom & 5 & 2 & \\
\hline Chi-square/degree of freedom & 4.71 & 1.86 & $1-5$ \\
\hline GFI & 0.98 & 1.00 & $0,90 \leq \mathrm{GFI} \leq 0,95$ \\
\hline AGFI & 0.93 & 0.98 & $0,85 \leq \mathrm{AGFI} \leq 0,90$ \\
\hline RMSR & 0.081 & 0.014 & $0,05 \leq \mathrm{RMSR} \leq 0,08$ \\
\hline RMSEA & 0.099 & 0.048 & $0,05 \leq \mathrm{RMSEA} \leq 0,08$ \\
\hline \multicolumn{4}{|l|}{ Incremental Fit Value } \\
\hline CFI & 0.97 & 1.00 & $0,95 \leq \mathrm{CFI} \leq 0,97$ \\
\hline NNFI & 0.97 & 0.99 & $0,95 \leq \mathrm{NNFI} \leq 0,97$ \\
\hline NFI & 0.93 & 0.99 & $0,95 \leq \mathrm{NFI} \leq 0,97$ \\
\hline
\end{tabular}

In the study, the research model examining the relationships between personal influence, selfmonitoring dimensions and status consumption was tested by path analysis. In the direction of the modifications suggested in the model, 3 variables, 2 variables from self-monitoring susceptibility dimension and 1 variable from the "informative" dimension of personal influence, were eliminated. Model fit values were on an acceptable level after modification. The results were shown in Table 6. 
Journal of Global Strategic Management | V. 4 | N. 2 | 2010-December | isma.info | 17-33 | DOI: 10.20460/JGSM.2010415822

\section{Table 6. Model Fit Values}

\begin{tabular}{|c|c|c|c|}
\hline Fit Index & Before Modification & After Modification & Acceptable Fit \\
\hline \multicolumn{3}{|c|}{ Absolute Fit Index } & \\
\hline Chi-square $\left(\mathrm{X}^{2}\right)$ & 641.00 & 196.51 & \\
\hline Degree of freedom & 221 & 97 & \\
\hline Chi-square/degree of freedom & 2.9 & 2.03 & $1-5$ \\
\hline GFI & 0.86 & 0.94 & $0,90 \leq \mathrm{GFI} \leq 0,95$ \\
\hline AGFI & 0.83 & 0.92 & $0,85 \leq \mathrm{AGFI} \leq 0,90$ \\
\hline RMSR & 0.12 & 0.051 & $0,05 \leq \mathrm{RMSR} \leq 0,08$ \\
\hline RMSEA & 0.079 & 0.52 & $0,05 \leq$ RMSEA $\leq 0,08$ \\
\hline \multicolumn{3}{|c|}{ Incremental Fit Index } & \\
\hline CFI & 0.94 & 0.98 & $0,95 \leq \mathrm{CFI} \leq 0,97$ \\
\hline NNFI & 0.93 & 0.97 & $0,95 \leq \mathrm{NNFI} \leq 0,97$ \\
\hline NFI & 0.92 & 0.96 & $0,95 \leq \mathrm{NFI} \leq 0,97$ \\
\hline
\end{tabular}

Standard coefficients, $\mathrm{R}^{2}$ values, $\mathrm{t}$ values, Cronbach's Alpha coefficients, construct reliability and variances were shown in Table 7.

\begin{tabular}{|c|c|c|c|c|c|c|}
\hline Variables & $\begin{array}{l}\text { Standard } \\
\text { Value }\end{array}$ & $\mathbf{R}^{2}$ & $\begin{array}{c}\text { Error } \\
\text { Variance }\end{array}$ & $\begin{array}{c}t \\
\text { Value }\end{array}$ & $\begin{array}{l}\text { Construct } \\
\text { Reliability }\end{array}$ & $\begin{array}{l}\text { Explanatory } \\
\text { Variance }\end{array}$ \\
\hline \multicolumn{7}{|l|}{ PERSONAL INFLUENCE (Cronbach's Alpha=0,871) } \\
\hline Normative(Cronbach's Alpha =0,778) & & & & & $\mathbf{0 , 8 6}$ & $\mathbf{0 , 6 1}$ \\
\hline $\begin{array}{l}\text { In social situations, I have the ability to alter my behavior if I feel } \\
\text { that something else is called for. }\end{array}$ & 0,70 & 0,49 & 0,78 & 12,31 & & \\
\hline $\begin{array}{l}\text { When I feel that the image I am portraying isn't working, I can } \\
\text { readily change it to something that does. }\end{array}$ & 0,85 & 0,73 & 0,41 & 15,03 & & \\
\hline $\begin{array}{l}\text { I have trouble changing my behaviors to suit different people and in } \\
\text { different situations*. }\end{array}$ & 0,88 & 0,77 & 0,34 & 15,36 & & \\
\hline $\begin{array}{l}\text { I have found that I can adjust my behavior to meet the requirements } \\
\text { of any situation in which I find myself. }\end{array}$ & 0,66 & 0,44 & 0,85 & 11,95 & & \\
\hline Informative $($ Cronbach's Alpha $=0,753)$ & & & & & $\mathbf{0 , 8 2}$ & $\mathbf{0 , 6 1}$ \\
\hline $\begin{array}{l}\text { If I have little experience with a product, I often ask my friends } \\
\text { about the product. }\end{array}$ & 0,74 & 0,55 & 0,46 & 10,47 & & \\
\hline $\begin{array}{l}\text { I often consult other people to help choose the best alternative } \\
\text { available from a product class. }\end{array}$ & 0,83 & 0,69 & 0,32 & 14,15 & & \\
\hline $\begin{array}{l}\text { I frequently gather information from my friends or family about a } \\
\text { product before I buy. }\end{array}$ & 0,76 & 0,58 & 0,51 & 13,48 & & \\
\hline \multicolumn{7}{|l|}{ SELF-MONITORING (Cronbach's Alpha =0,682) } \\
\hline Self-Monitoring Ability (Cronbach's Alpha a=0,677) & & & & & 0,68 & $\mathbf{0 , 5 9}$ \\
\hline $\begin{array}{l}\text { In social situations, I have the ability to alter my behavior if I feel } \\
\text { that something else is called for. }\end{array}$ & 0,67 & 0,46 & 0,45 & 10,38 & & \\
\hline $\begin{array}{l}\text { When I feel that the image I am portraying isn't working, I can } \\
\text { readily change it to something that does. }\end{array}$ & 0,73 & 0,49 & 0,43 & 12,05 & & \\
\hline Self-Monitoring Susceptibility $($ Cronbach's Alpha $=0,653$ ) & & & & & $\mathbf{0 , 6 0}$ & $\mathbf{0 , 3 5}$ \\
\hline $\begin{array}{l}\text { I am often able to read people's true emotions correctly (through } \\
\text { their eyes). }\end{array}$ & 0,67 & 0,45 & 0,51 & 8,05 & & \\
\hline $\begin{array}{l}\text { My powers of intuition are quite good when it comes to } \\
\text { understanding the emotions and motives of others. }\end{array}$ & 0,73 & 0,54 & 0,43 & 7,45 & & \\
\hline $\begin{array}{l}\text { I can usually tell when I've said something inappropriate } \\
\text { by reading it in the listener's eyes. }\end{array}$ & 0,60 & 0,43 & 0,50 & 4,38 & & \\
\hline \multicolumn{7}{|l|}{ STATUS CONSUMPTION (Cronbach's Alpha =0,867) } \\
\hline I would buy a product just because it has status. & 0,80 & 0,63 & 0,55 & 10,35 & $\mathbf{0 , 8 4}$ & $\mathbf{0 , 5 7}$ \\
\hline I am interested in new products with status & 0,85 & 0,73 & 0,39 & 17,31 & & \\
\hline I would pay more for a products if it had status & 0,82 & 0,67 & 0,51 & 16,64 & & \\
\hline A product is more valuable to me if it has some snob appeal. & 0,51 & 0,26 & 0,88 & 9,79 & & \\
\hline
\end{tabular}


The values belonging to construct reliability of the variables in the research model were on an acceptable level. The relationships between personal influence and self-monitoring and status consumption were shown in Table 8 .

\begin{tabular}{|l|c|c|c|c|}
\hline \multicolumn{1}{|c|}{ Table 8. Relations Among Variables of Research Model } \\
\hline \multicolumn{1}{|c|}{ Variables } & $\begin{array}{c}\text { Standard } \\
\text { Value }\end{array}$ & $\mathbf{R}^{\mathbf{2}}$ & $\begin{array}{c}\text { Error Vari- } \\
\text { ance }\end{array}$ & $\begin{array}{c}\mathbf{t} \\
\text { value }\end{array}$ \\
\hline SELF-MONITORING ABILITY-SELF-MONITROING & 0,92 & 0,92 & 0,08 & 5.35 \\
\hline SELF-MONITORING SUSCEPTIBILITY-SELF-MONITORING & 0,45 & 0,34 & 0,66 & 4.96 \\
\hline INFORMATIVE-PERSONAL INFLUENCE & 0,61 & 0,35 & 0,65 & 9,08 \\
\hline NORMATIVE-PERSONAL INFLUENCE & 0,91 & 0,94 & 0,06 & 12,22 \\
\hline SELF-MONITORING-STATUS CONSUMPTION & 0,15 & 0,64 & 0,36 & 2,22 \\
\hline PERSOANL INFLUENCE-STATÜS CONSUMPTION & 0,53 & 0,64 & 0,36 & 7,11 \\
\hline
\end{tabular}

As shown in Table.8 and Figure.2, personal influence and self-monitoring have an impact on status consumption. These findings show that social approval, social comparison and behaving suitably to others have an effect on status consumption. Additionally, we can say that social surroundings, particularly reference groups, affect this kind of consumption.

In the previous researches and studies on status and conspicuous consumption, it was found out that personal influence and self-monitoring had an impact on status consumption (Kilsheimer, 1993; O'Cass and McEwen, 2005; Wong, 1997). The results obtained in this research support the literature. In this case, $\mathrm{H} 2$ and $\mathrm{H} 3$ hypotheses were confirmed.

Figure 2. Research Path Model

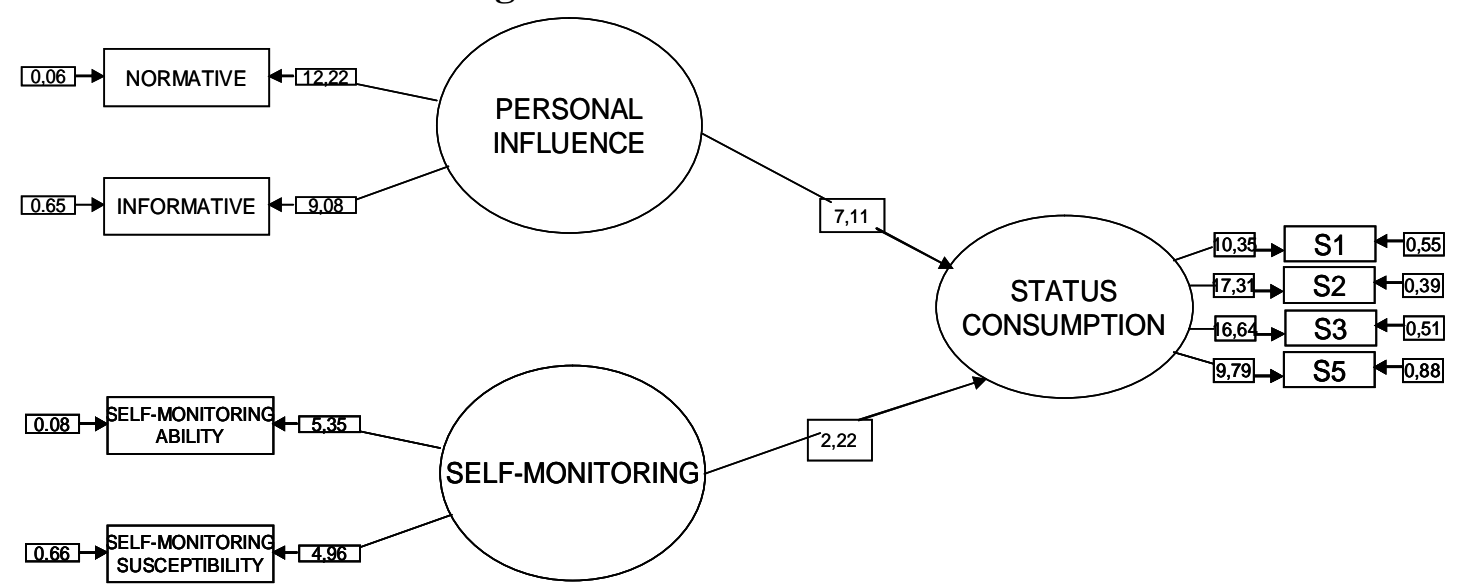

\section{Relationships between brand preferences and status con- sumption behaviors of respondents}

Correlation analysis was conducted to determine whether there was a relationship between brand preferences and status consumption of the respondents. According to the results of the analysis, there is a significant relationship between status consumption and domestic-foreign brand preferences. In other words, respondents with high status consumption prefer to buy foreign branded products. Thus, of the hypotheses of the study, H1 was confirmed. The results were shown in Table 9.

\begin{tabular}{|l|l|l|}
\hline \multicolumn{2}{|c|}{$\begin{array}{c}\text { Table 9. Relationship Between Status Consumption and } \\
\text { Domestic-Foreign Brand Preferences }\end{array}$} \\
\hline & & Brand Preference \\
\hline Status Consumption & Correlation coefficient & -0.097 \\
\hline & Sig & $0,025^{*}$ \\
\hline
\end{tabular}

$* \mathrm{p}<0.05$ 
As is known, in status and conspicuous consumption, individuals benefit from the symbolic meanings of the products to give messages to the surrounding others. In brand preferences as well, symbolic meanings that brands have are determinative. Therefore, in both status and conspicuous consumption, prestige brands are preferred, and brands and products supporting social status in status consumption are preferred more. Marcoux, Filiatrault and Cheron (1997), in their study, investigated the preference levels of students for foreign branded products in their status consumption. According to the results of the research, students with a high tendency towards ostentation prefer foreign brands. O'Cass and McEwen (2005) examined prestige brand preferences both for status and conspicuous consumption. According to the results, prestige brand preference is high both for status and conspicuous consumption. The results of this study are consistent with the other studies. In status consumption, prestige and foreign brands are preferred more. Therefore, H1 hypothesis was confirmed.

\section{CONCLUSION}

In this study, the effects of personal influence and self-monitoring on status consumption were investigated. Additionally, domestic and foreign brand preferences of individuals with high status consumption were examined. According to the results, personal influence and self-monitoring have an impact on status consumption. Accordingly, the effect of social surroundings, particularly of reference groups, is high for those doing status buying. Normative and informal interaction was found to be important in communication with social surroundings. This situation shows that individuals try to be attuned to their surrounding environment by gathering information and imitating. Again, in status consumption, self-monitoring having an impact shows that they are susceptible in perceiving and adjusting the surrounding environment. At the same time, they prefer prestige and foreign brands in their brand preferences.

The following can be suggested according to the results:

Firms offering products for status consumption should concentrate on strategies that have symbolic meanings supporting social status in positioning their products because consumers doing status buying expect products to support their social status. If messages sent involve meanings of distinction, respect and status in their brand retention strategies, it will be effective for the brands to be approved. Again, personal influence will be more effective in the retention of these brands than mass media because consumers doing status buying evaluate their surroundings as an important source of information.

It was determined that prestige brands were preferred in status consumption. Domestic prestige brands are preferred in status consumption; however, foreign brands are preferred more. In this case, it will be useful for the domestic brands to compete both at home and abroad if they expand to foreign markets and become a global brand. Global brands will meet the status symbol expectations of foreign and domestic markets.

\section{Limitations and implications}

In this study, status consumption tendencies of the consumers towards domestic and foreign ready-towear brands were examined. When status consumption tendencies are taken into consideration for different product groups, more information can be obtained about their preferences for status consumption since, unlike conspicuous consumption, brands preferred in status consumption are not expected to be expensive. It is enough for the brand to have a symbol of status and support the ideal self of consumers. Therefore, status consumption tendencies of consumers towards inexpensive product groups and characteristics of products that are influential for this tendency can be examined.

In the study, the effect of personal influence and self-monitoring on status consumption was investigated. In the future studies to be carried out to contribute to status consumption literature, the psychographic characteristics of the consumers and the factors influential on consumers' perception of status brands can be searched. 


\section{REFERENCES}

Aaker, Jennifer L.(1999). The Malleabl Self: The Role of Self-Expression in Persuasion, Journal of Marketing Research,_February, 36, 1, pp.45-57.

Abe, S., Bagozzi, R.P., and Saderangani P. (1996). An Investigation of Construct Validity and Generalizability of the Self-Concept:Self-Consciousness in Japan and the United States, Journal of International Consumer Marketing, 8, 3-4, pp.97-123.

Amaldoss, W., and Jain, S. (2005). Conspicuous Consumption and Sophisticated Thinking, Management Science. 51, 10, pp.1449-1466.

Bearden, O.W., Netemeyer, R. G., and Teel, J. E. (1989). Measurement of Consumer Susceptibility to Interpersonal Influence, Journal of Consumer Research, 15, 4, pp.473-481.

Bearden, O.W., Shuptrine, F.K., and Teel, J. E.. (1989). Self-Monitoring and Reactions To Image Appeals and Claims About Product Quality”. Advances in Consumer Research, 16, pp.703-710.

Chen, J., (2002). Chinese Identification, Acculturation and Conspicuous Consumption in a Multicultural Society: A Theoretical Framework and Emprical Evidence, The University of Guelph, Phd. Dissertation, UMI.

Chen, J., Aung, M., Zhou, L., and Konektör, V. (2005). Chinese Ethnic Identification and Conspicuous Consumption: Are There Moderators or Mediators Effect of Acculturation Dimensions?, Journal of International Consumer Marketing, 17, 2/3, pp.117-136.

Darley, K. W., and Lim, J.S. (1992). The Effect of Consumers Emotional Reations on Behavional Intention: The Moderating Role of Personel Relevence and Self-Monitoring, PsychologyandMarketing, 9, 4, pp.329-346.

Eastman, K. J., Fredenberger, B., Campbell, D., and Calvert S. (1997). The Relationship Between Status Consumtion and Materialism: A Cross-Cultural Comparison of Chinese, Mexican, and American Students, Journal of Marketing Theory and Practice, pp.52-66.

Eastman, K.J., Goldsmith, R. E., and Flynn, L. R.(1999). Status Consumption in Consumer Behaviour: Scale Development and Validation, Journal of Marketing Theory and Practice. Summer, pp.41-52.

Escalas, J. E., and. Bettman, J. R. (2005). Self-construal, Reference Groups and Brand Meaning, Journal of Consumer Research, 32, 3, pp.378-389.

Ford, J. D., and Ellis, E. (1980). A Re-Examination of Group Influence on Member Brand Preference, Journal of Marketing Research, 17, pp.125-132.

Goldsmith, R.E., Clark, R. A., and Goldsmith, E. B. (2006). Extending the Psychological Profile of market Mavenism, Journal of Consumer Behaviour, 5, 411-419.

Graeff, R. T. (1996). Image Congruence Effects on Product Evalutions: The Role of Self-Monitoring and Public/Private Consumption, PsychologyandMarketing, 13, 3, pp.235-266.

Hair, J., Anderson, R., Tatham, and Black, W. (1998). Multivariate Data Analysis with Readings. 5th ed., Prentice- Hall

Harnish, J. R., and Bridges, K. R. (2006). Social Influence: The Role of Self-Monitoring When Making Social Comparisons, PsychologyandMarketing, 23, 11, pp.961-973.

Heaney, J.G., Goldsmith, R. E., and Jusoh, W. J. W. (2005). Status Consumption Among Malaysion Consumers: Exploring Its Relationships with Materialism and Attention-to-Social-ComparisonInformation, Journal of International Consumer Marketing, 17(4), pp.83-98. 
Hog, K.M., Cox, A. J., and Keeling, K. (2000). The Impact of Self-Monitoring on Image Congruence and Product/Brand Evaluation, Europen Journal of Marketing, 34, 5/6, pp.641-666.

Hong, W. J., and Zinkhan, G. M. (1995). Self-Concept and Advertising Effectiveness: The Influence of Congruency, Conspicuousness and Response Model, PsychologyandMarketing, 12, 1, pp.53-77.

Kilsheimer, J. C. (1993). Status Consumption: The Development and Implications of A Scale Measuring the Motivation to Consume For Status, The Florida State University, Phd. Dissertation, UMI.

Koç, E. (2007). Tüketici Davranışı ve Pazarlama Stratejileri: Global ve Yerel Yaklaşım, Consumer Behaviour and Marketing Strategies: Global and Local Approach, Seçkin Yayıncılık San. ve Tic.A.Ş, Ankara.

Lammers, H.B. (2002). Moderating influence of Self Monitoring and Gender on Responses to Humorous Advertising, The Journal of Social Psychology, 131, 1, pp.57-79.

Loroz, P. S. (2004). Golden-age Gambling:Psychological Benefits and Self-Concepts Dynamics in Aging Consumers Consumption Experiences, PsycholoyandMarketing, 21, 5, pp.323-349.

Marcoux, J. S., Filiatrault, P., and Cheron, E. (1997). The Attitudes Underlying Preferences of Young Urban Educated Polish Consumers Towards Products Made in Western Countries, Journal of International Consumer Marketing, 9, 4, pp.5-29.

Mason, R. (2001), Conspicuous Consumption: A Literature Review, European Journal of Marketing, 18, 3, pp.26-39.

Mowen, C. J. (1993). Consumer Behavior. Third Edition, Macmillan Publishing Compony, USA.

O'Cass, A., and McEwen, H. (2005). Exploring Consumer Status and Conspicuous Consumption, Journal of Consumer Behaviour, 4, 1, pp.25-39.

O'Cass, Aron., (2000), A Psychometric Evaluation of a Revised Version of the Lennox and Wolfe Revised Self-Monitoring Scale, PsychologyandMarketing, 17(5), pp.397-419.

Polat, Z. S., and Umay, A. (2002). Kendini Gösterim Özelliğinin Öğretmenlik Mesleği ile İlişkisi [Relationships Self monitoring properties and tearchership profession], Hacettepe Üniversitesi Eğitim Fakültesi Dergisi, 23, pp.198-204.

Ratner, K. R., and Kahn, B. E. (2002). The Impact of Private Versus Public Consumption on VerietySeeking Behavior, Journal of Consumer Research, 29, pp.246-257.

Reed, II A. (2002). Social Identitiy as a Usefull Perspective for Self-Concept-Based Consumer Research, PsychologyandMarketing, 19, 2, pp.235-266.

Ricks, J., and Veneziaro, L. (1998). The effect of Gender and Selected Personality Traits on Objective and Subjective Measures of Sales Performance. The Journal of Marketing Management, Fall/Winter, pp.7-21.

Roberts, A. J. (2000). Consuming in a Consumer Culture: College Students, Materialism, Status Consumption, and Compulsive Buying, Marketing Management Journal, Fall/Winter, pp.76-91.

Roberts, A.J., Gwin, C. F., and Martinez, C. R. (2004). The Influence of Family Structure on Consumer Behaviour: A Re-Inquiry and Extension of Rindfleisch Et al.1997 in Mexico. Journal of Marketing Theory and Practice.Winter. pp.61-79.

Rose, P., De Jesus, S. P. (2007). A Model of Motivated Cognition to Account fort he Link Between Self-Monitoring and Manterialism, PsychologyandMarketing, 24, 2, pp.93-115.

Sandra, L. T. S. (2002). A study of Consumer's Self and Purchasing Behaviour in Fashion Brand Image Marketing, The Hong Kong Polytechnic University, Phd. Dissertation UMI. 
Shavitt, S., Lowrey, T. M., and Han, S. P. (1992). Attitude Functions in Advertising: The Interactive Role of Products and Self-Monitoring, Journal of Consumer Psychology, 1,4, pp.337-364.

Solomon, R. M. (2007). Consumer Behavior, Buying, Having, and Being. Seventh Edition, Pearson Prentice Hall. USA.

Spangerberg, R.E., Sprott, D. F. (2006). Self Monitoring and Susceptibility to the Influence of SelfProhecy. Journal of Consumer Research, 32, 4, pp.550-556.

Wee, T. T. T., and Ming, M. C. H. (2003). Leveraging on Symbolic values and Meanings in Branding, Brand Management, 10, 3, pp.208-218.

Wong, N.Y.C. (1997). Suppose You Own the World and No One Knows? Conspicuous Consumption Materialism and Self, Advances in Consumer Research, 24, pp.197-203. 


\section{APPENDIX}

\begin{tabular}{|c|c|c|}
\hline Variables & Mean & $\begin{array}{l}\text { Standard } \\
\text { Deviation }\end{array}$ \\
\hline \multicolumn{3}{|l|}{ NORMATIVE } \\
\hline I rarely purchase the latest fashion styles until I am sure my friends approve of them. & 3,1830 & 1,35895 \\
\hline It is important that others like the products and brands I buy. & 3,5968 & 1,16546 \\
\hline When buying products, I generally purchase those brands that I think others will approve of. & 3,4759 & 1,18444 \\
\hline If other people can see me using a product, I often purchase the brand they expect me to buy. & 3,6300 & 1,20365 \\
\hline I like to know what brands make good impressions on others. & 3,0508 & 1,25131 \\
\hline I achieve a sense of belonging by purchasing the same products and brands that others purchase. & 3,7721 & 1,11156 \\
\hline If I want to be like someone, I often try to buy the same brands they buy. & 4,0427 & 1,15777 \\
\hline I often identify with other people by purchasing the same products and brands they purchase. & 3,8556 & 1,14873 \\
\hline \multicolumn{3}{|l|}{ INFORMATIVE } \\
\hline To make sure I buy the right product or brand, I often observe what others are buying and using. & 3,2987 & 1,29432 \\
\hline If I have little experience with a product, I often ask my friends about the product. & 2,4213 & 1,13692 \\
\hline I often consult other people to help choose the best alternative available from a product class. & 2,5027 & 1,15239 \\
\hline I frequently gather information from my friends or family about a product before I buy. & 2,6080 & 1,20978 \\
\hline
\end{tabular}

\begin{tabular}{|c|c|c|}
\hline \multicolumn{3}{|c|}{ Table 11: Mean and Standard Deviation Values of Self-Monitoring Scale } \\
\hline Variables & Mean & $\begin{array}{r}\text { Standard } \\
\text { Deviation }\end{array}$ \\
\hline \multicolumn{3}{|l|}{ SELF MONITORING ABILITY } \\
\hline In social situations, I have the ability to alter my behavior if I feel that something else is called for. & 2,0185 & 1,00642 \\
\hline $\begin{array}{l}\text { I have the ability to control the way I come across to people, depending on the impression I wish to } \\
\text { give them. }\end{array}$ & 2,2414 & 1,02240 \\
\hline $\begin{array}{l}\text { When I feel that the image I am portraying isn't working, I can readily change it to something that } \\
\text { does. }\end{array}$ & 3,1702 & 1,24269 \\
\hline I have trouble changing my behaviors to suit different people and in different situations*. & 2,1524 & 1,22344 \\
\hline $\begin{array}{l}\text { I have found that I can adjust my behavior to meet the requirements of any situation in which I find } \\
\text { myself. }\end{array}$ & 2,9706 & 1,22384 \\
\hline Once I know what a situation calls for, it's easy for me to regulate my actions accordingly & 2,5559 & 1,06436 \\
\hline \multicolumn{3}{|l|}{ SELF MONITORING SENSITIVITY } \\
\hline I am often able to read people's true emotions correctly (through their eyes). & 2,1733 & 1,07441 \\
\hline $\begin{array}{l}\text { In conversations, I am sensitive to even the slightest change in the facial expression of the person } \\
\text { with whom I am conversing. }\end{array}$ & 2,1640 & 1,10920 \\
\hline $\begin{array}{l}\text { My powers of intuition are quite good when it comes to understanding the emotions and motives of } \\
\text { others. }\end{array}$ & 2,1878 & 1,10660 \\
\hline $\begin{array}{l}\text { I can usually tell when others consider a joke to be in bad taste, even though they may laugh con- } \\
\text { vincingly. }\end{array}$ & 3,3008 & 1,35665 \\
\hline I can usually tell when I've said something inappropriate by reading it in the listener's eyes. & 2,2361 & 1,10847 \\
\hline If someone is lying to me, I usually know that it at once from that person's manner of expression. & 2,6781 & 1,24587 \\
\hline
\end{tabular}

*Reversed question 
Journal of Global Strategic Management | V. 4 | N. 2 | 2010-December | isma.info | 17-33 | DOI: 10.20460/JGSM.2010415822

\begin{tabular}{|c|c|c|}
\hline \multicolumn{3}{|c|}{ Table 12: Status Consumption } \\
\hline Variables & Mean & $\begin{array}{l}\text { Standard } \\
\text { Deviation }\end{array}$ \\
\hline I would buy a product just because it has status. & 2,9800 & 1,2242 \\
\hline I am interested in new products with status & 3,0088 & 1,1950 \\
\hline I would pay more for a products if it had status & 3,0462 & 1,2395 \\
\hline The status of s product is irrelevant to me.* & 3,5297 & 1,2353 \\
\hline A product is more valuable to me if it has some snob appeal. & 3,3297 & 1,2945 \\
\hline
\end{tabular}

*Reversed question 